\title{
The Effects of Urban and Economic Development on Coastal Zone Management
}

\author{
Davide Pasquali $^{1, *(D)}$ and Alessandro Marucci ${ }^{2}$ (D) \\ 1 Environmental and Maritime Hydraulic Laboratory (LIAM), Department of Civil, Construction-Architectural \\ and Environmental Engineering (DICEAA), University of L'Aquila, 67100 L'Aquila, Italy \\ 2 Department of Civil, Construction-Architectural and Environmental Engineering (DICEAA), University of \\ L'Aquila, 67100 L'Aquila, Italy; alessandro.marucci@univaq.it \\ * Correspondence: davide.pasquali@univaq.it
}

check for updates

Citation: Pasquali, D.; Marucci, A. The Effects of Urban and Economic Development on Coastal Zone Management. Sustainability 2021, 13, 6071. https://doi.org/10.3390/ su13116071

Academic Editors: Daniela Malcangio, Alan Cuthbertson, Juan Tomás García-Bermejo, Alessandra Saponieri, Janek Laanearu and Marc A. Rosen

Received: 25 February 2021

Accepted: 20 May 2021

Published: 28 May 2021

Publisher's Note: MDPI stays neutra with regard to jurisdictional claims in published maps and institutional affiliations.

Copyright: (C) 2021 by the authors. Licensee MDPI, Basel, Switzerland. This article is an open access article distributed under the terms and conditions of the Creative Commons Attribution (CC BY) license (https:// creativecommons.org/licenses/by/ $4.0 /)$.
Abstract: The land transformation process in the last decades produced the urbanization growth in flat and coastal areas all over the world. The combination of natural phenomena and human pressure is likely one of the main factors that enhance coastal dynamics. These factors lead to an increase in coastal risk (considered as the product of hazard, exposure, and vulnerability) also in view of future climate change scenarios. Although each of these factors has been intensively studied separately, a comprehensive analysis of the mutual relationship of these elements is an open task. Therefore, this work aims to assess the possible mutual interaction of land transformation and coastal management zones, studying the possible impact on local coastal communities. The idea is to merge the techniques coming from urban planning with data and methodology coming from the coastal engineering within the frame of a holistic approach. The main idea is to relate urban and land changes to coastal management. Then, the study aims to identify if stakeholders' pressure motivated the deployment of rigid structures instead of shoreline variations related to energetic and sedimentary balances. The influence of coastal protection (described by an indicator taking into account the linear density of the rigid protection extension alongshore) measures have been considered. Finally, the economical performances in the period just after the land transformation have been studied by means of a dimensionless index based on the concept of the local unit. The method has been applied to the case study of the Abruzzo Region. Results reveal a large urbanization growth and a generalized over-protection of the coast with a resulting spatial alternation of shoreline retreat and advance. On the other hand, the analysis of the local economy reveals that the presence of tourism activities does not necessarily lead to an increase in the local economy. Indeed, the most important improvement in local economies in the region can be associated with coastal stretches characterized by a high environmental value.

Keywords: climate change; coastal management; coastal protection; shoreline evolution; shoreline evolution; urban growth

\section{Introduction}

In the last 50 years, there was an increase in anthropic pressure on coastal areas e.g., [1-4]. As underlined by Mentaschi et al. [5], coastal environments host about $40 \%$ of the world's population as well as infrastructures, tourism, and social activities. Coastal municipalities in Italy are 645 , covering a total area of about $43,000 \mathrm{~km}^{2}$, equivalent to $14 \%$ of the entire national territory with a population of about $17,200,000$ inhabitants. As confirmed by Romano et al. [6], since the 1950's, the peninsula had seen a strong land transformation process. The increase of urbanization in coastal areas highlights a surprising match in per-capita urbanized areas among many Italian regions, in line with the western European Union average $\left(360 \mathrm{~m}^{2} /\right.$ inhabitant), although they started off from very different situations in the 50s. As a consequence, this process triggered the threat of extreme form of a dispersion in the key areas of national landscapes and ecosystems (i.e., protected 
areas and Nature 2000 sites) e.g., [6]. The reasons for this evolution may be related to the economy and morphology of the different regions which make up the Italian territory. In particular, there are two main sectors composing the national longitudinal development in the North-South direction, the Adriatic and Tyrrhenian one, while the Jonic sector is only in the southern part [7]. From an urban point of view, it is clear that the coastal environment represents a complex geographical area. Indeed, in the last 50 years, the anthropic pressure has caused change of $90 \%$ of the coastal environment, leaving intact less than $10 \%$ of the original habitats. Moreover, the population density in marine areas is more than twice the national mean (not considering the seasonal and touristic fluctuations). The Italian Institute of Statistics (ISTAT) reveals that 30\% of the Italian people live in the 646 coastal municipalities. In addition, the main national infrastructures are developing (also due to the orography) near the shorelines (on the dune areas). Indeed, flat areas facilitate infrastructure construction compared to areas with a more complicated orography. Moreover, coastal areas are attractive for their pleasant weather conditions, especially during the summer, then by promoting the increase of anthropic pressure. This occurrence was a key factor for the Mediterranean transport and consequently for maritime trade e.g., [8]. From the Second World War until the present, the change in population in Italy is $+64 \%$ for the Adriatic coast, $+38 \%$ for the Jonic coast, $+72 \%$ for the Tyrrhenian one, and $+44 \%$ for the islands (Sicily and Sardinia). In the same period (1950-2018) the percentage variations of the urbanization areas are $+474 \%$ for the Adriatic coast, $+914 \%$ for the Jonic coast,$+627 \%$ for the Tyrrhenian one, and $+666 \%$ for the islands. Figure 1 synthesizes the variations at the national scale. Considering the area extending $500 \mathrm{~m}$ inland from the shoreline, the urbanization is two times the value it was in the 1950s to the 2000s, ranging from $10 \%$ to $21 \%$. Several authors e.g., [2,9] agree that after the Second World War, the urbanization rate is about $10 \mathrm{~km}^{2} /$ year.

All these aspects enhance the attention over this geographic district, which shows a great dynamism both at present and in the past. Furthermore, in the last decades, attention is given to coastal erosion all over the world. The Eurosion project [10] in 2004 points out that the total amount of eroded coastal areas around the European Union's is about 20\% of the total extension. Italy has approximately $8000 \mathrm{~km}$ of shoreline e.g., [10] (at national scale), where $50 \%$ is sandy beaches, $15 \%$ rocky /hard, and $28 \%$ soft rock coasts, respectively. The remaining part is artificial ( $7 \%)$. On the national scale, in Italy, it has been estimated that around $30 \%$ of the shoreline is affected by erosive phenomena e.g., [10].
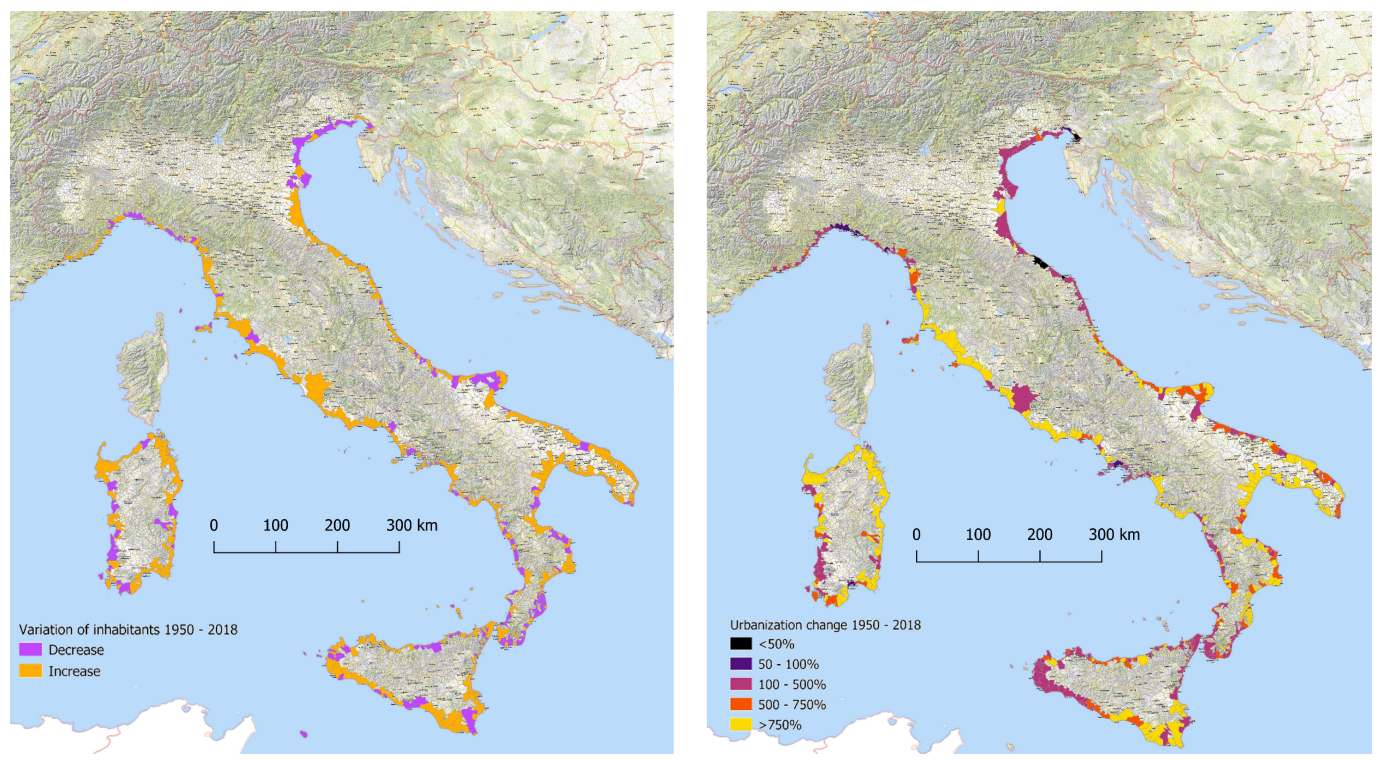

Figure 1. Urbanization change in Italy in the period 1950-2018.

The phenomenon of beach dynamics is originally natural and contributed over the centuries to shape the coastal landscape. However, it is also true that the migration of 
humans towards the marine areas and strong modification of internal areas (i.e., with the deployment of artificial reservoirs and the protection of watersheds from erosion) induced unavoidable interference in the coastal environments e.g., [11]. Therefore, at present, it is commonly accepted that the phenomenon of coastal dynamics is affected by both natural and human factors. Problems are amplified due to the lack of sediments that often remain trapped in artificial reservoirs [12] and harbors, and in general, due to all the phenomena inducing a decrease in river sediments e.g., [13]. Moreover, large volumes of sediments are lost for the progressive dismantling of dunes because of anthropic pressures e.g., [14,15], as well as for vertical land movements (i.e., subsidence) due to natural phenomena (i.e., tectonics), anthropic activities (e.g., groundwater table drop) and sediment compaction that determines a decrease of sediment supply e.g., [16,17]

The damages suffered by dune systems could reach a threshold that makes the consequences irreversible e.g., [18] reducing their fundamental role in coastal dynamics e.g., $[1,19]$.

This situation must be considered also in view of the future possible scenarios of climate change. Indeed, one of the major climate change effects on the marine area is the rise of sea level (SLR). Combining the effect of the SLR with the increase of the frequency of strong storms, wind, and storm surge e.g., [20-25], in the near future there will be the increase of flooding e.g., [26] impacting on the hazard (and then on risk) of the urbanized or protected areas on the coast e.g., [21,27]. The Intergovernmental Panel on Climate Change (IPCC) stressed e.g., [21] that, even without the SLR, presently, there is evidence that confirms inter-annual changes in inundations e.g., [28]. The resulting interaction between land use planning and managing is a recent open question in the literature e.g., [29].

The controlling of coastal dynamics is often performed by "soft" and "hard" techniques e.g., $[15,30,31]$. One of the most employed soft solutions is beach nourishment, devoted to restoring the sediment budget re-introducing sand on the beach e.g., [32-35] (i.e., paying particular attention to geomorphological and sedimentological characterization e.g., [36-38]). Hard solutions are rigid structures parallel (emerged or submerged breakwaters e.g., [39-41]) or perpendicular (groins e.g., [42]) to the shoreline aiming at reducing the energy of the incoming waves in the first case and decreasing (totally or partially) the longshore transport [43] intercepting the sediment transport in the latter case e.g., [44]. For a more detailed description of these coastal processes, readers may refer to e.g., $[43,45,46]$. Despite the difference in aims and impacts, experience has shown that there are no correct or incorrect solutions, but often the best results have been reached by combining soft and hard solutions e.g., [47].

Although the large-scale sediment budget is not influenced by hard structures, they are effective in restoring beaches at their deployment sites. Nevertheless, boundary effects can influence the morphodynamics of downdrift areas e.g., [30]. Therefore, these effects must be taken into account with care at the design and monitoring stages.

On the other hand, nourishment has a beneficial impact on the beach uses but is a temporary solution that needs maintenance. There is no general rule to solve the problem, but a possible way to mitigate the effects comes from coastal management that implies a general analysis of the possible cause-and-effect relationship between urbanization, land-use, and coastal dynamics with attention paid to sustainability.

In this context, this paper aims to analyze how urbanization, and in general the urban development (used as a proxy of the economic growth), can influence coastal management and, therefore, the possible resulting executions of coastal interventions. In particular, attention is paid to how the economy has affected the coastal management policies, rather than the possible effects of coastal dynamics on the economy. The case study of the Abruzzo Region is chosen to highlight the applicability of the proposed method to a real case.

In particular, considering that the possible response of a natural system is a long-term process, the idea of the work is to refer to two different time spans. The evolution of urbanization e.g., [6] has been evaluated in the period 1950-2000 (i.e., the forcing factor) while the shoreline variation is referred to in the period 2001-2018 (i.e., the response to 
coastal management policies). The urbanization changes in the span of 2001-2018 are not considered, as it is assumed that the effects of coastal management are delayed with respect to the coastal management measures.

Moreover, the shoreline changes are analyzed taking into account the hard defense system built along the coast. A final analysis is devoted to understanding how the development of urbanization has impacted the economy of the municipality of the studied Region.

The paper is structured as follows. Section 2 describes the methodology for urban analysis and morphological evaluation. Section 3 illustrates the features of the case study and available data, Section 4 discusses the obtained results. Concluding remarks close the paper.

\section{Methodology}

As previously underlined, the great variation of urban cover in Italy and other countries were in the period ranging from the 50s to the end of the twentieth century. Starting from this evidence, the main idea of the work is to investigate the possible link between urban development (and a consequent change in land use) and coastal dynamics. The possible effects of human activities on the environment are often referred to a long-term scale, then the effects can be observed shifted in time. Then, urban variations and shoreline evolution are refer to different time spans. The first are evaluated considering the difference of the urbanization values in 1950 and in 2000 (hereinafter referred to as $\Delta_{U R B}\left[\mathrm{~m}^{2}\right]$ ), while the latter is referred to the shoreline extracted for the years 2001 and 2018. The state of urbanization of the Italian coast on a municipal basis and its evolution were determined through the use of data deriving from the study by Romano et al. [7]. This dataset resulted from elaborating data of the Italian National Institute for Environmental Protection and Research (ISPRA) [48]. Following the suggestions given by Syvitski et al. [12], the evaluation of the morphodynamics and urban information have been evaluated using the concept of Radius of Influence of Coastal Erosion (RICE) [10,47]. The influence areas (hereinafter referred to as IA) can be defined considering an area characterized by an extension up to $500 \mathrm{~m}$ landward [10,47]. The extension toward the sea is $2500 \mathrm{~m}$, i.e., up to the typical width of morphodynamics active beach zone extending up to the depth of closure e.g., [49,50].

Considering only the sandy coasts (i.e., by neglecting the phenomena related to cliff erosion and coastal dynamics) the shoreline variation has been analyzed by using a diachronic analysis by considering the local total variation $(\mathrm{m})$ of the shoreline positions between two different epochs $\left(\Delta Y_{i, i+1}\right)$ for each IA (see Figure 2a). The evaluation of $\Delta Y_{i, i+1}$ requires (for each IA) the definition of transversal direction to the shoreline and the geographical location of each i-th position. In more details, the mean location of the shoreline of each IA for each epoch has been evaluated. Consequently, the transversal direction is the orthogonal line to the mean value of the mean positions (see Figure $2 b$ ) between the considered epochs. It is then possible to evaluate the mean displacement of the shoreline in the given $j$-th IA as:

$$
\Delta Y_{i, i+1}^{(j)}=\overline{\Delta Y(x)_{i, i+1}}
$$

where $x$ is the coordinate in the longitudinal direction (locally parallel to the shoreline) and $Y$ the transversal direction (locally perpendicular to the shoreline).

Going deeper into details (see Figure $2 b$ ), within each area of influence, the direction along which shoreline displacements are evaluated must be defined $(\bar{n})$. Then, for each IA, the direction $\left(\bar{n}_{j}\right.$, being $j$ the $j$-th area of influence) has been defined as the spatial mean of the local normal directions to the shoreline at epoch $i$ at all the points belonging to the given IA. The local normal directions $\left(n_{k}\right)$, being $k$ the points belonging to the IA) have been estimated by employing a finite-difference first-order scheme with a centered stencil. Figure $2 \mathrm{~b}$ shows a qualitative sketch representing the methodology described above. 


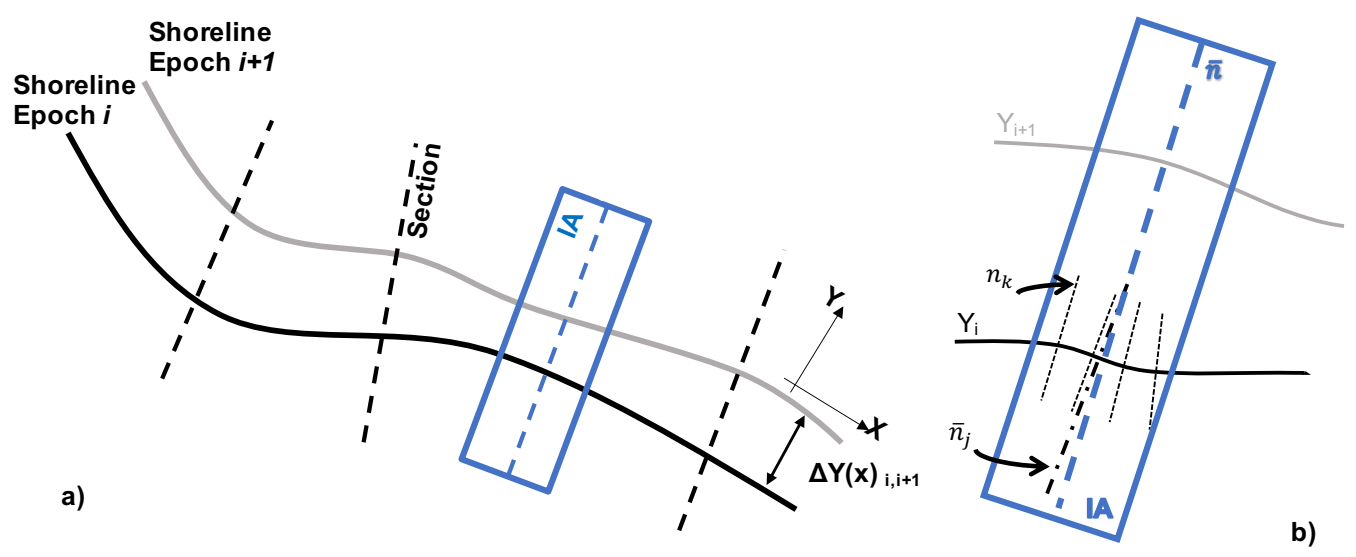

Figure 2. Qualitative sketch of the method used for the evaluation of shoreline evolution. Panel (a) shows the general scheme of the methodology while panel (b) is a zoom on the IA for the definition of the shoreline normal direction.

As far as the shoreline data are concerned, the data come from available datasets. Through these data, using whatever procedure, the shoreline position in two different epochs must be extracted (see Section 3.3 for details about the extraction of the shoreline for the case study).

Historically, at least at the national scale in Italy, the use of breakwaters is the most used practice to defend coastal areas against erosion e.g., [31]. More recently, groins are deployed along with breakwaters in order to avoid loss of sediment in particular after beach nourishment. Therefore the situation is a prevalent alternation of groins and breakwaters (emerged and submerged). In order to assess the influence of rigid protection (that locally influenced the nearshore hydrodynamic inducing variation in the whole management area) on the changes in the shoreline position, a "Protection Index" (hereinafter referred to as PI) is proposed herein. More in details, although a correct interpretation of the influence of the rigid structures on shoreline variation should be carried out using at least a one-line model e.g., [51-53], considering the aim of the work (not focused on the hydro- and morphodynamic details) the index is intended to relate marine structures to shoreline evolution from a phenomenological point of view.

The $P I$ is a dimensionless measure of the length of the rigid protection alongshore ( $\left.L_{\text {structures }}\right)$ against the total extension of the shoreline $\left(L_{\text {shoreline }}\right)$ for each IA:

$$
P I=\frac{L_{\text {structures }}}{L_{\text {shoreline }}} \text {. }
$$

This index is lower than one when the shoreline length in the IA is lower than the linear extension of the rigid protection and one when the two values are equal (i.e., the total extension of the shoreline in the IA is protected by a longitudinal breakwater).

Changes in the coastal area (both concerning shoreline variation and urban growth) suggest an investigation into the possible effect (direct or indirect) on the local economy. The analysis has been carried out using the Local Unit variable, as suggested by the European Union [54]. The Local Unit (hereinafter referred to as $L U$ ) is defined by the European Law as: "an enterprise or part thereof (e.g., a workshop, factory, warehouse, office, mine or depot) situated in a geographically identified place. At or from this place economic activity is carried out for which - save for certain exceptions-one or more persons work (even if only part-time) for one and the same enterprise" [54]. The specific variables of LUs are the localization, the typology (classified based on the Classification of Economic Activity, ATECO 2007 code) and the number of employees. Only the ATECO codes directly related to as "coastal resource" have been considered herein. This choice is motivated by the aim to consider the "coastal resource" as the main driver of the local scale economy. Therefore 
only the categories with a direct correlation with touristic activity have been considered i.e., hotels, accommodation services, house rental, car leasing, tour operators, etc.

These data are often available only at the municipality scale. Therefore, to adapt this information to the influence area scale, also in this case an Index of Local Units (hereinafter referred to as $I L U$ ) has been proposed:

$$
I L U=\Delta \%,
$$

where $\Delta \%$ is the percentage variation of the $L U$ in a given time span and for each municipality. It has to be stressed that $I L U$ values are assumed constant over the areas of the considered municipality. Table 1 resumes all the proposed indexes.

Table 1. List of the proposed index.

\begin{tabular}{c} 
PI $\begin{array}{r}\text { Dimensionless measure of the weight of the rigid protection extension both } \\
\text { alongshore and cross-shore }\left(L_{\text {structures }}\right) \text { against the total extension of the } \\
\text { shoreline }\left(L_{\text {shoreline }}\right) \text { for each IA }\end{array}$ \\
\hline ILU \\
$\begin{array}{r}\text { Percentage variation of the LU in a given time span and for each municipality. It } \\
\text { is constant over the areas in which the municipality is divided }\end{array}$ \\
\hline $\begin{array}{l}\text { Shoreline variations evaluated by using a diachronic analysis by considering the } \\
\text { local total variation }(\mathrm{m}) \text { of the shoreline positions between two different epochs } \\
\left(\Delta Y_{i, i+1}\right) \text { for each IA }\end{array}$ \\
\hline$\Delta_{\text {URB }}$
\end{tabular}

\section{The Case Study of the Abruzzo Region}

\subsection{Site Description}

The case study is a stretch of the Adriatic coast on the Abruzzo Region, in Central Italy. The coastal area includes 19 municipalities, with a total coastline length of about $130 \mathrm{~km}$. From a morphological point of view, it is heterogeneous with features characterized by a low and sandy coast and others mainly high and rocky, which are not subjected to erosion processes.

The Adriatic coast, like the Tyrrhenian one, was the protagonist of compulsive urbanization that has increased about four times, assuming a current value of over $11 \%$. A rate of increase that was almost similar also along the central-northern Tyrrhenian coast. Soil transformation rates were very pronounced: in the Adriatic coastal municipalities an urban conversion of over $0.04 \mathrm{~km}^{2}$ / day can be estimated, but, considering the development of the linear front of the coast, an urbanization speed of almost $10 \mathrm{~km} /$ year from the postwar period to today can be estimated [55]. Starting from the north, the coastal area is characterized by a preponderance of sandy beaches with the presence of a protected marine area ("Torre del Cerrano"). There are productive and touristic activities that have encouraged an increase in human activity over the years. The presence of the Giulianova harbor (see Figure 3) and the A24 highway make this area one of the most developed of the entire region. At the center, there is another section characterized by low and sandy beaches. This area contains the metropolitan city of Pescara, the main economic hub of the entire Region. This central area ends with the channel port of the Pescara River. The harbor is connected to the highway and the near Abruzzo airport (the only one in the Region). Moving to the south, the Ortona harbor identifies a non-homogeneous area from a morphological point of view. South from Pescara, there is an area with low and sandy beaches, on the contrary near Ortona harbor the coast is mainly composed of high and rocky coasts. On the contrary to the northern and central parts of the Region, in this section, there is a massive presence of agricultural activities not inland from the coast. The remaining part of the coast is mainly rocky (with some long sandy beaches exceptions) and ends in correspondence of the Trigno's river mouth. Here, the regional protected area named "Riserva naturale Punta Aderci" stretches from the attractive beach of Punta Penna, near the Vasto harbor, up to the Sinello's river mouth (at the southern boundary of the municipality of Casalbordino). 
The total length of the shoreline prone to be eroded is about $98 \mathrm{~km}$, the $79.3 \%$ of the total extension of the shoreline. To counteract the erosion phenomena, during the last 60 years, a series of "hard" and "soft" interventions have been made (see Figure 4). Actually, the total length of the rigid structures (seawalls, groins, and breakwaters, both emerged and submerged) is about $60 \mathrm{~km}, 49 \%$ of the total coastal length (considering only the sandy beaches, about $60 \%$ ).

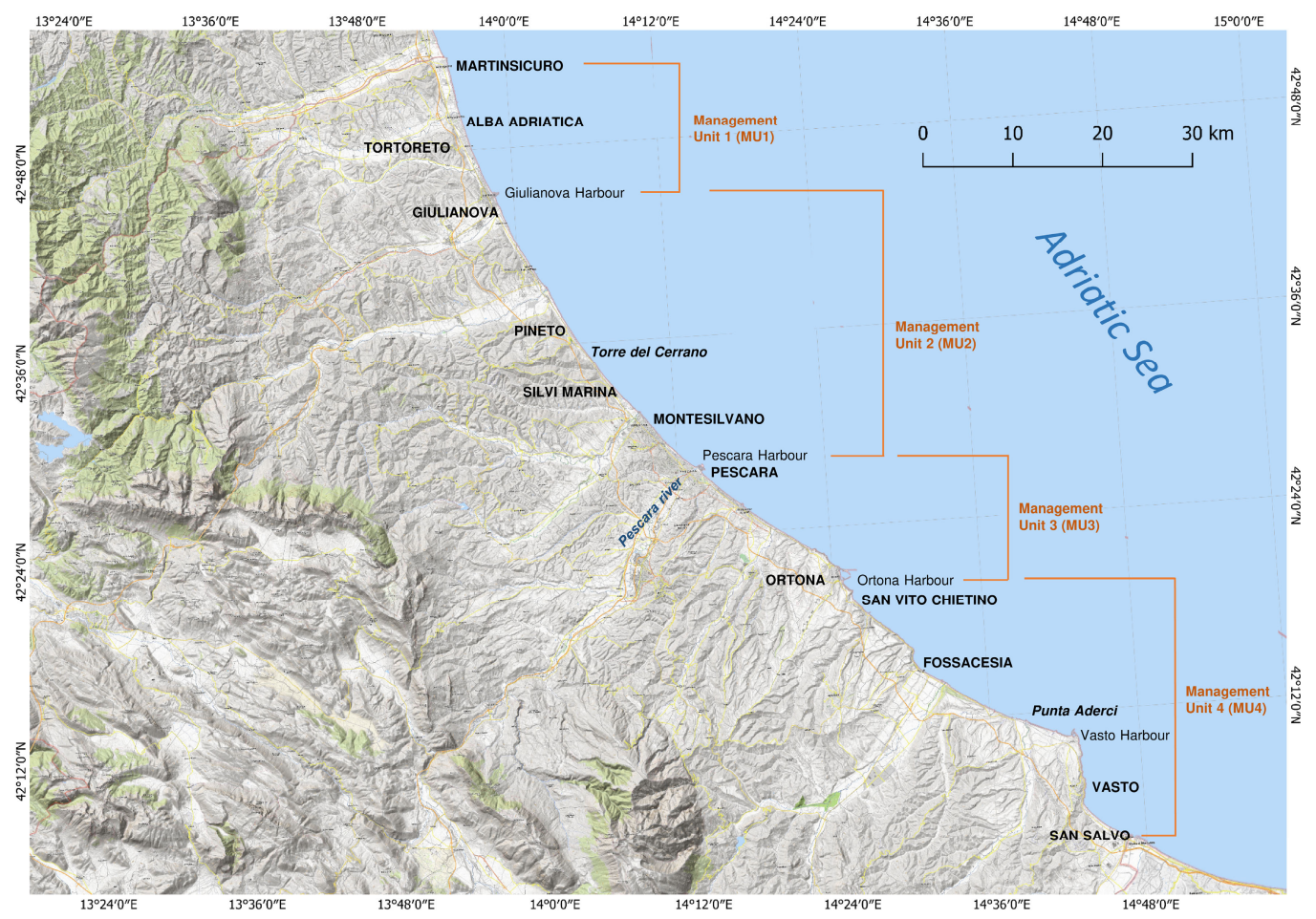

Figure 3. Sketch of the study Area.
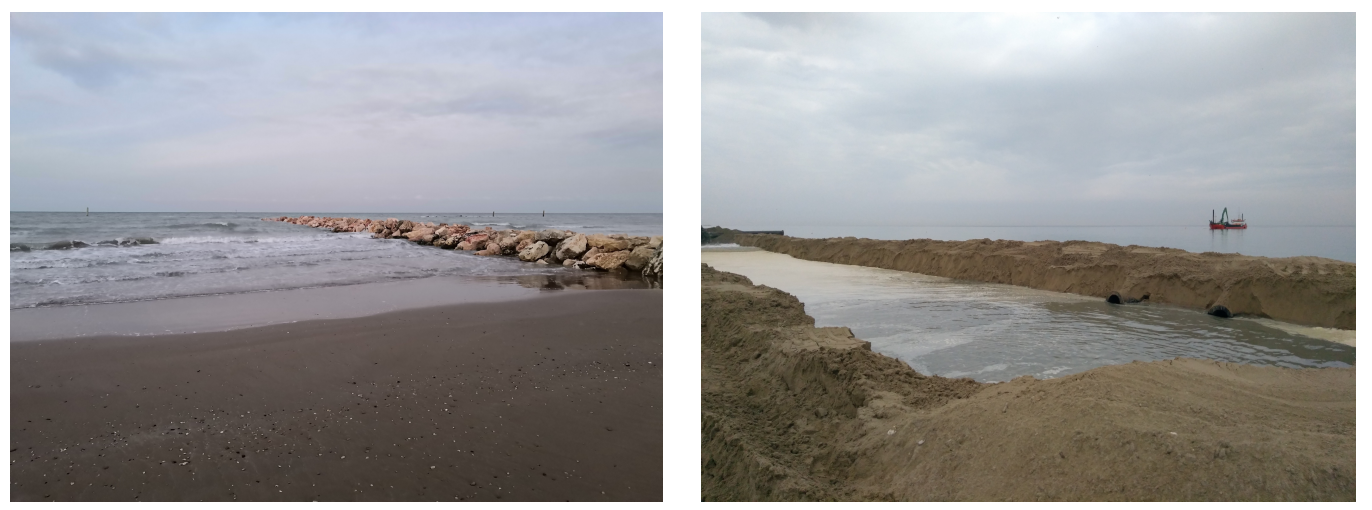

Figure 4. Examples of "hard" (left panel) and "soft" (right panel) interventions.

\subsection{Management Unit Definition}

Looking at the sediment transport, due to the presence of the four ports, and considering the local economies, the Abruzzo Region could be split into four "management units" (hereinafter referred to as MU) depicted in Figure 5.

On the other hand, looking at the population variation it is possible to divide the Region into two different sectors: a northern and a southern part bounded by the metropolitan city of Pescara. This is mainly due to the different morphological features of the coast. The northern area is prone to be intensively urbanized due to the flat areas near the shoreline. As previously underlined the southern area, instead (south to the metropolitan area of Pescara), is characterized by an alternation of rocky and sandy beaches influencing urbanization and land use. It is possible to find these features also in the economic framework. 
The area north of Pescara harbor contains infrastructures for touristic activities, companies, and is well connected with the northern area of the Italian peninsula. The situation is different in the south of the Region where the coast's features do not favor the exploitation of coastal touristic activities. Nevertheless, the morphological configuration of this area has retained the environment, by promoting the institution of areas characterized by high environmental value. Indeed, the Abruzzo Region has nine terrestrial protected areas, two in the northern part and seven in the southern area, confirming the role of urbanization in the progressive change of nature and environment. The areas recognized by the European Commission as a site of community importance (ZPSs) in Abruzzo are 6, all in the southern Area [56-58].

\subsection{Data}

The data concerning the urbanization evolution can be referred to the ISPRA database. However, the raw data have been analyzed by using the method proposed by Romano et al. [7]. The original study of [7] analyzed the land transformation for the Italian peninsula. Here, a subset of the analyzed data concerning only the Abruzzo Region data for the period 1950-2000 (consistently with the proposed parameter $\Delta_{U R B}$ ) have been used. For a more detailed description, readers may refer to [7].

Following the main aim of this study (see Section 2), the shoreline has been extracted considering the time span 2001-2018 using rectified orthophotos (2001) and satellite images (2018). Both have been re-sampled with a dimension of $0.25 \mathrm{~m}$ for each pixel. Therefore, the resulting pixel dimension is $0.25 \times 0.25 \mathrm{~m}$. Based on the pixel dimensions and re-sampling the algorithm of the shoreline extraction a total displacement of $5 \mathrm{~m}$ (i.e., $\pm 0.25 \mathrm{~m}$ /year) has been used to assess the stability of coastal stretches (i.e., neither in advance nor in retreat). The reason for the selection of these two epochs lies in the aim of the proposed indicators to catch the long-term evolution of the shoreline that is assumed to be delayed with respect to the coastal management measures. The automatic procedure was implemented based on the pixel-by-pixel analysis within the RGB space. More in detail, each image has been indexed by using the RGB information (i.e., lower than a given threshold identified with a sensitivity analysis) in order to discriminate the water and the land e.g., [59]. The interface has been then identified. Then, the raw results of the automatic procedure were manually checked, and if needed, amended to meet the real configuration of the shoreline as visualized in the images (either orthophoto or satellite image). Thereafter, the shoreline was further corrected by using the measured tidal level (as extracted from the time series collected at Ortona using the mareographic station belonging to National Tidal Gauges Network) and by estimating a mean emerged beach slope (as estimated based on the LIDAR survey performed by National Authorities). More specifically, the LIDAR data has been used to estimate the slope of the emerged beach. Then the slope has been utilized to correct the shoreline location by taking into account the synchronous tidal level collected in the Ortona station.

The same procedure has been implemented in order to extract all the protection structures insisting on the coast.

Finally, the economic data from the Italian National Institute of Statistics (ISTAT) have been used. The available period was 2011-2017 only at the municipal scale. From all the database, as previously described, only the ATECO 2007 codes referred to activities related to the coastal economy have been used.

\section{Results and Discussion}

The coastal stretch of the Abruzzo Region, following the methodology detailed in Section 2, waswas divided into 780 IAs (with an average alongshore extension of $200 \mathrm{~m}$ ), with 628 IAs referring to the sandy coast. Results reveal that starting from 1950, there was a mean increase in the population of $+128 \%$ while urbanization reaches $+718 \%$. In the northern part, the population variations were only positive, and the municipality of Montesilvano has the highest value of increment equal to $+635 \%$ while the total variation 
of urbanization is equal to $+1800 \%$. The southern area, instead, was characterized by small variation (either positive or negative), except for Vasto and San Salvo. The reason lies in the recent development of coastal tourism. Indeed, in recent years, the Abruzzo Region has invested in the tourism promotion of its territory through the Strategic Tourism Plan (2017-2019), particularly in the Teatina coast (where Vasto and San Salvo belong). Besides, the mentioned municipalities are those with greater availability of sandy beaches, more suitable for seaside tourism. Looking inside the change rate in the urbanization of the coastal and maritime areas, instead, the situation is growing everywhere. Speaking about the land take speed in the Abruzzo Region it is possible to say that before 2000, the average land take speed was equal to $17,500 \mathrm{~m}^{2} /$ day. As for the general behavior of the Italian Peninsula, the Abruzzo Region has its maximum increase in urbanization between 1960 and 1980, started to decrease from 1980 and 1990 and has stabilized between 1990 and 2010. At present, the rate is almost unchanged and future inferential projection until 2050 does not show significant variations [60].

Figure 5 shows the variation of urbanization in the whole coastal area of the Region while Figure 6 describes more in detail the Urban change for each management unit.

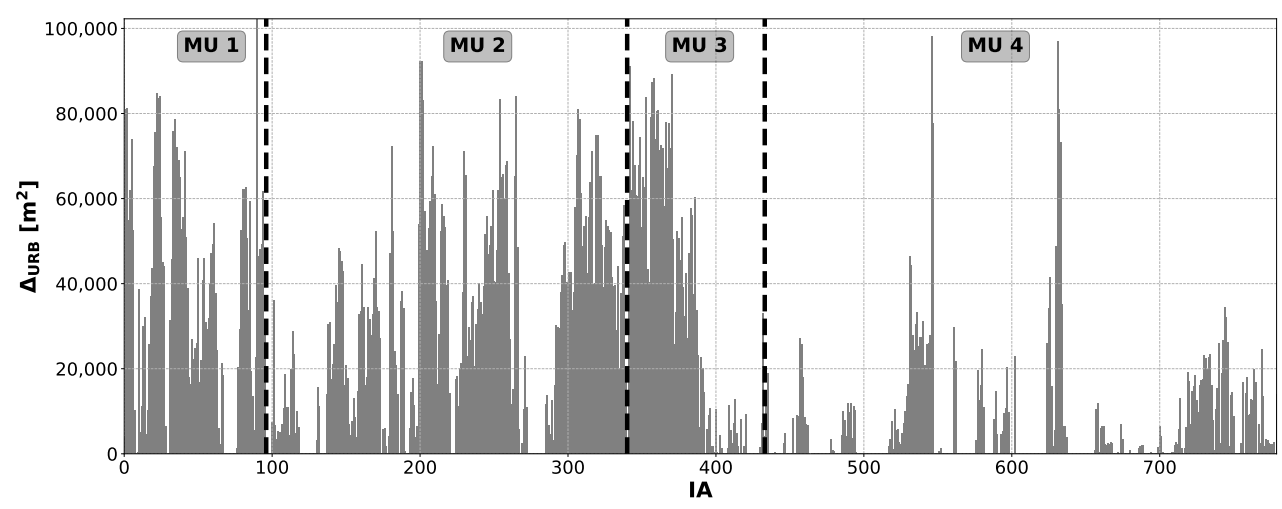

Figure 5. Urbanization variation in Abruzzo Region in the period 1950-2000. The dashed vertical lines indicate the boundaries of MUs.

As previously underlined, in order to investigate the long-term effect of the urbanization growth, the shoreline variation between the epochs 2001 and 2018 has been investigated. The variations have been evaluated from north to south using Equation (1).

The obtained results (see Figure 7) reveal the impossibility to define a general trend describing the evolution of the shoreline in all the considered management units. There is a clear alternation of retreats and advances of the shoreline against the always positive trend of urban growth.

In general, sediments tend to remain trapped in the updrift area near each port delimiting each MU. This aspect is expected considering the main direction of the sediment transport in the Abruzzo Region (waves mainly come from the north).

In the northern part, the highest retreat of the shoreline is observed, in particular in the first management unit where the extension and width of the retreats are evident and localized far from the Giulianova harbor (IAs 89-90).

The second MU, between Giulianova and Pescara harbors is characterized by a similar pattern of the first MU, a shoreline advance near the ports. The third management unit shows, instead, a general trend to shoreline growth, except for some local hot-spots. 

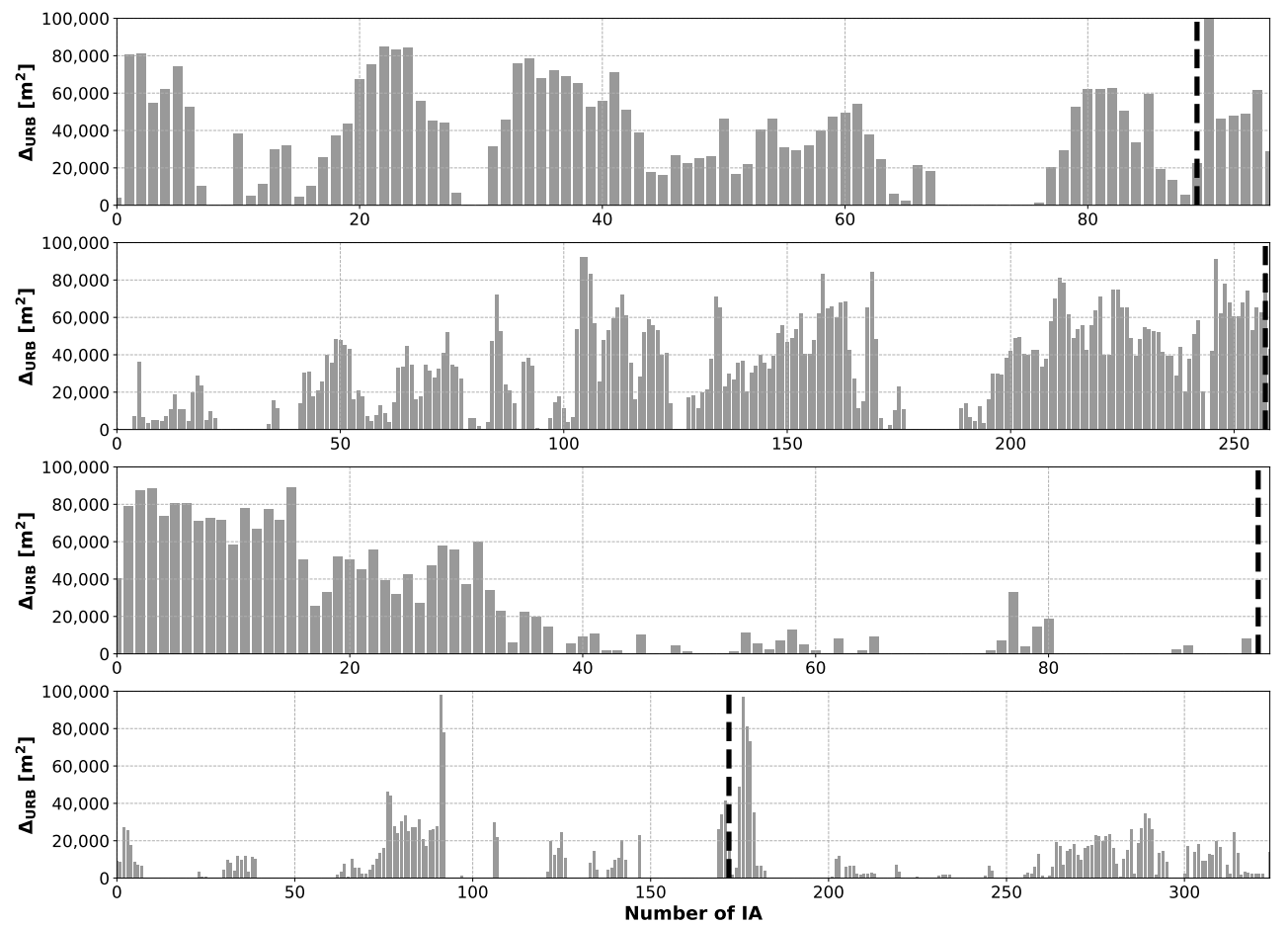

Figure 6. Urbanization growth in the period 1950-2000 for each Management Unit (see Figure 5). Results are arranged in descending order from north to south from the first management unit (upper panel) to the fourth one (lower panel). The dashed vertical lines indicate the harbor.
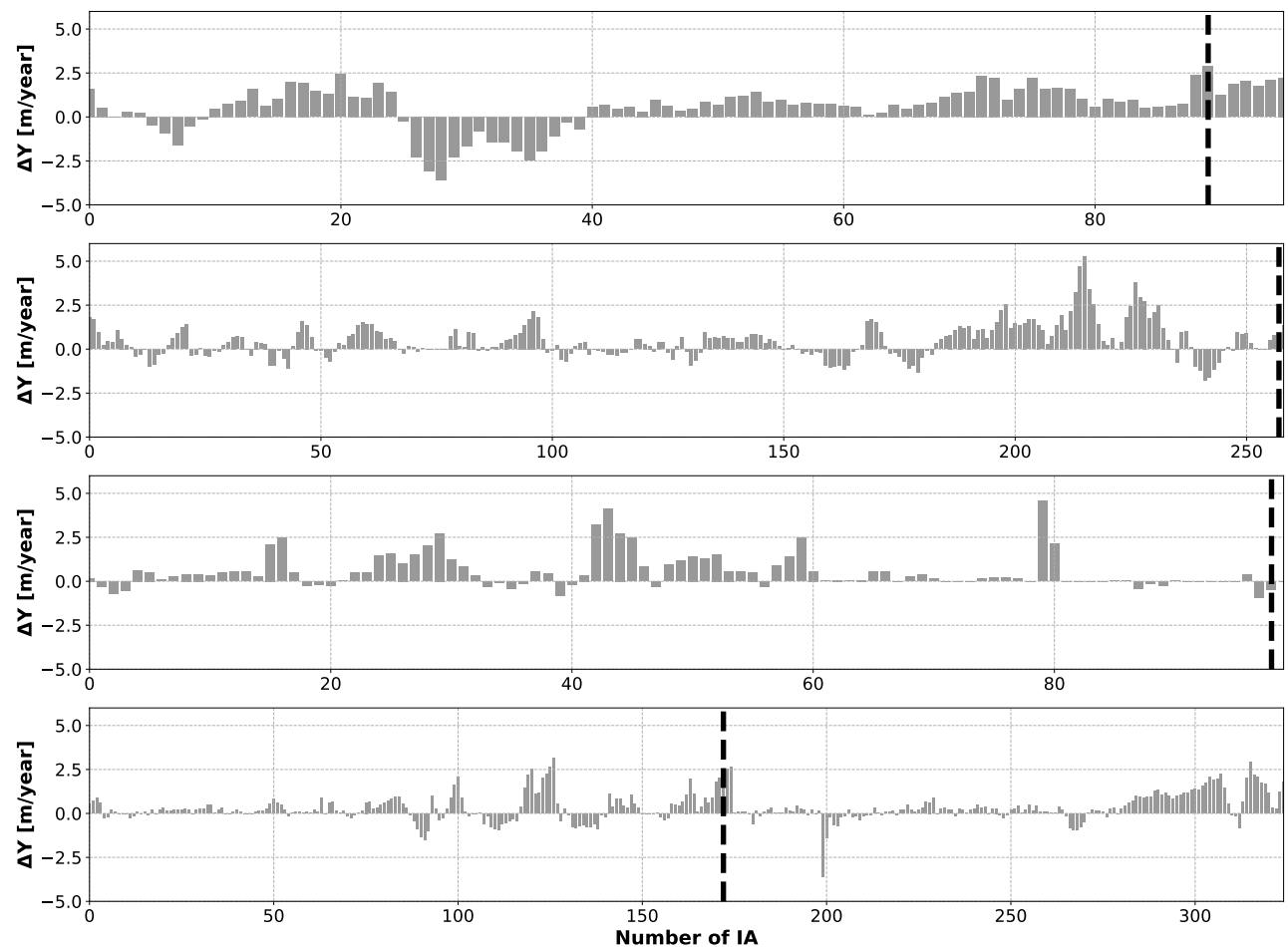

Figure 7. Shoreline variation in the period 2001-2018 for each Management Unit (see Figure 5). Results are arranged in descending order from north to south from the first management unit (upper panel) to the fourth one (lower panel). The dashed vertical lines indicate the harbor.

In order to assess the effect of the coastal defense systems on the shoreline evolution, the Protection Index has been evaluated for the considered case study. Typically for the whole Adriatic coast, the stretch of the Adriatic coast on the Abruzzo Region has a large fraction of the coast protected by groins and breakwaters (both emerged and submerged). 
Figure 8 shows the protection index. It has to be noticed that the protection structures have been built from the early 60s up until today, therefore it is not possible in this case to indicate a fixed time period as for the variation in urbanization and shoreline.

However, the inspection of Figure 7 reveals that, aside from the first management unit, where only the northern part is not protected by the structures, in other cases the total amount of protection covers almost all their extension. It is also quite clear that in most cases, due to an increase of urbanization (therefore to an increase of exposure of the area) corresponds to a growth in coastal defense. This evidence confirms the direct and close relationship between urban growth, expansion and the following protection of coastal zones. The causal relationship is mutual. Urbanization influenced the natural coastal evolution, i.e., by affecting the coastal dunes system. On the other hand, the presence of building, infrastructures, and economic activities has led to an increase of beach width demand. Shoreline retreat threatened private houses, streets, or economic activities increasing the risk. Therefore, adopted solutions were to plan beach nourishment and rigid defense even if other possible solutions could have been ecological, and biological remediation aimed to increase beach width by promoting natural morphodynamics.
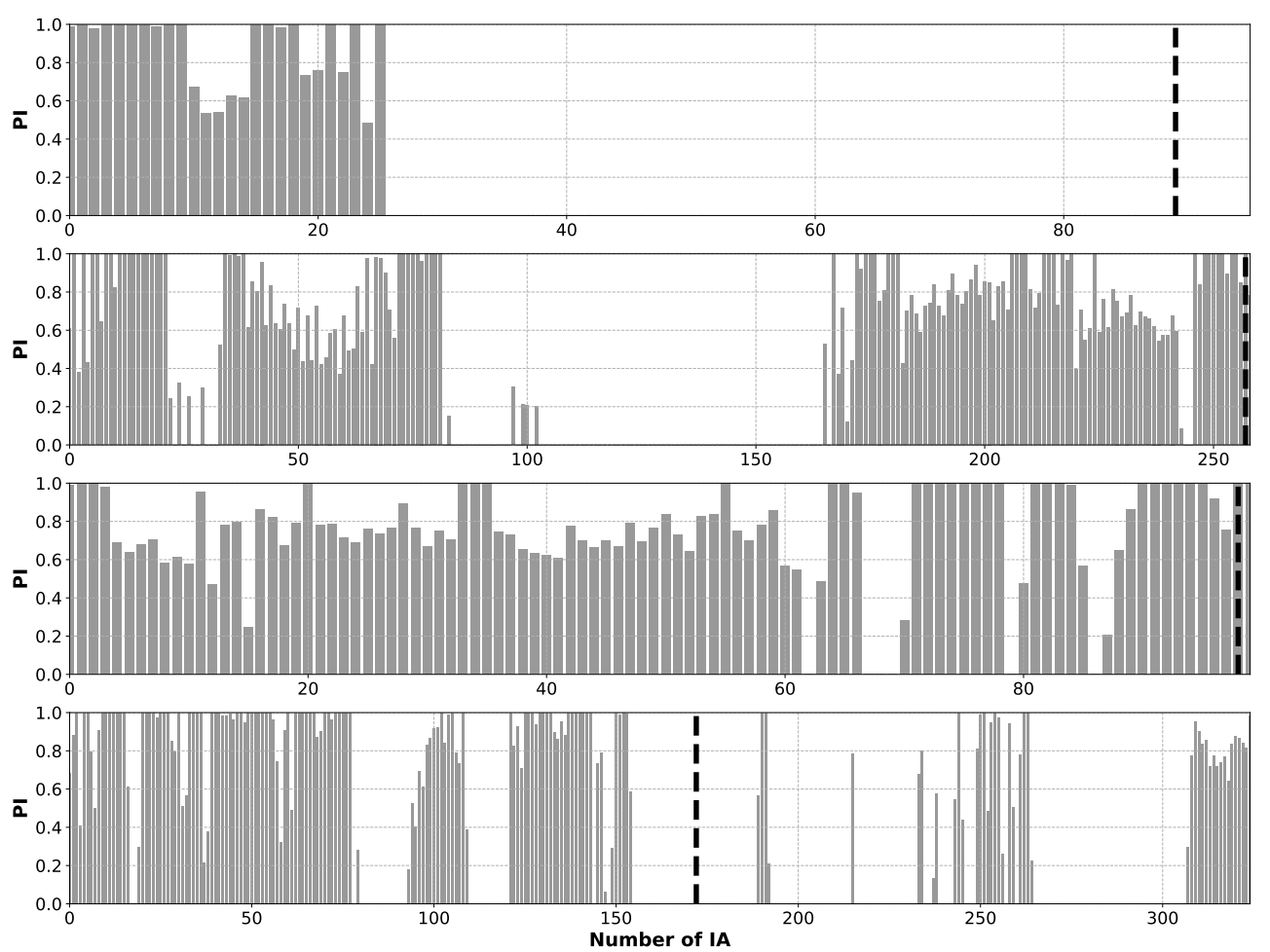

Figure 8. Evolution of the Protection Index in the Management Units (see Figure 5). The Results are arranged in descending order from north to south from the first management unit (upper panel) to the fourth one (lower panel). The dashed vertical lines indicate the harbor.

However, comparing the results shown in Figures 7 and 8 it is possible to observe that although the PI is in a lot of cases equal or close to one, there is an alternation of retreats and advances of the shoreline. Furthermore, it is difficult to give an unambiguous interpretation of the role of the rigid structure against coastal dynamics. As expected, an increase of protection in the same area, reveals a general tendency in advancement in the shoreline position. Nevertheless, despite a large amount of defended areas, the shoreline changes in response to urban growth are always characterized by an alternation of positive and negative values. This is likely related to two main factors. On the one hand, the coastal defense works were firstly carried out at river mouths: the trigger effect is related to the decrease of sediment transport from rivers. This occurrence is mainly due to the sediment that remains trapped in a series of artificial reservoirs (e.g., Campotosto and Bomba Lakes), and a series of small dams for hydroelectric energy generation insisting on the Region. 
On the other hand, boundary effects of coastal works have enhanced the erosion process on the downdrift areas.

Trying to move deeper inside the relationship between protection, shoreline variations, and urbanization, it is possible to qualitatively analyze some evidence in the MUs.

The first MU is characterized by protection only in the northern sector (25 IAs, see Figure 8) and almost all the breakwaters have been built in the period 1989-1997. Looking at the shoreline variation it is clear that, in the first 25 IAs, the structures achieved their goal. Indeed, despite some IAs where a small retreat happened (in the downdrift area of a small protected area for small fishing boats), the shoreline shows positive variations. In that areas, a series of groins have been placed in order to counteract the retreat. However, the downdrift stretch (up to the IA number 40) shows an evident retreat of the shoreline and no protection has been placed in this case. Nevertheless, it has to be stressed that it is difficult to directly correlate the presence of the structures and the shoreline retreat in the downdrift area. Indeed, the shoreline retreat can be related to the lack of sediments rather to the boundary effects of updrift coastal structures. In this sector, the urbanization variation is always positive, but there are some areas with zero variation, probably induced by the lack of available beaches for touristic enjoyment. After this sector (IAs 25-40, first $\mathrm{MU})$, the effects of the harbor in retraining sediment are evident. Indeed, no structures are needed and the shoreline grows everywhere. The urbanization variations are always positive, but some areas near the Salinello's river mouth characterized by the presence of a great number of green areas.

In the second MU there is the presence of two protected areas "Riserva Naturale Del Borsacchio" and "Torre del Cerrano". In both cases, as it is possible to see in the Figure 8 there are no protection structures. In the other stretch of the MU, instead, the PI is always positive. The great amount of the structures were deployed in the decade 1988-1998 and only some new structures have been realized in the last twenty years. As previously underlined it is difficult to assert what is the real benefit of rigid protection. In general, the alternation of advances and retreats combined with the small amount of the advance in shoreline position, does not allow an easy interpretation of the actual situation. It is interesting to note that the area near the Pescara harbor (physical limit of this MU, realized in 1989) is characterized by high values of $\Delta_{U R B}$. The effect of the harbor in trapping the sediment is evident in the positive $\Delta Y$ values. The area has been protected since 1989 by a series of breakwaters.

Moving to the south, the third MU shows a non-uniform growth in urbanization. The section with wider development is the nearest to the metropolitan city of Pescara while the remaining part of the MU has been left quite intact. The shoreline variations show a general non-negative behavior, with a general advance. This is probably because the third MU is almost completely protected by rigid structures (realized in the decade 1988-1998). The low urbanization values combined with the protection strategy probably lead to this situation. It is worth noting the newest protection structures, realized in 2007, are located downdrift of the Pescara harbor to counteract the negative values of $\Delta Y$, preserving the economic activities and the enjoyment of the beach.

Finally, the MU 4 is in general characterized by low values of $\Delta_{U R B}$. The $\Delta Y$ is characterized by an alternation of advances and retreats. As is possible to observe in Figure 8 the area has a great number of IAs with high PI values. The non-protected areas are related to the regional protected area of "Riserva naturale di Punta Aderci" and to some areas with no sandy beaches. In this case, a great number of structures are referred to 1988-1998. The new constructions (i.e., groins, breakwaters) from the period 2007-2019 are in general localized works, complete an existing protection system and account for $25 \%$ of the total amount of rigid structures of the entire coastal stretch. Figure 9 shows a general overview of the temporal evolution of the PI in the entire coastal stretch while Figure 10 shows some details of selected areas for each MU in order to highlight the analysis that has been carried out for taking a census of the rigid protections. 


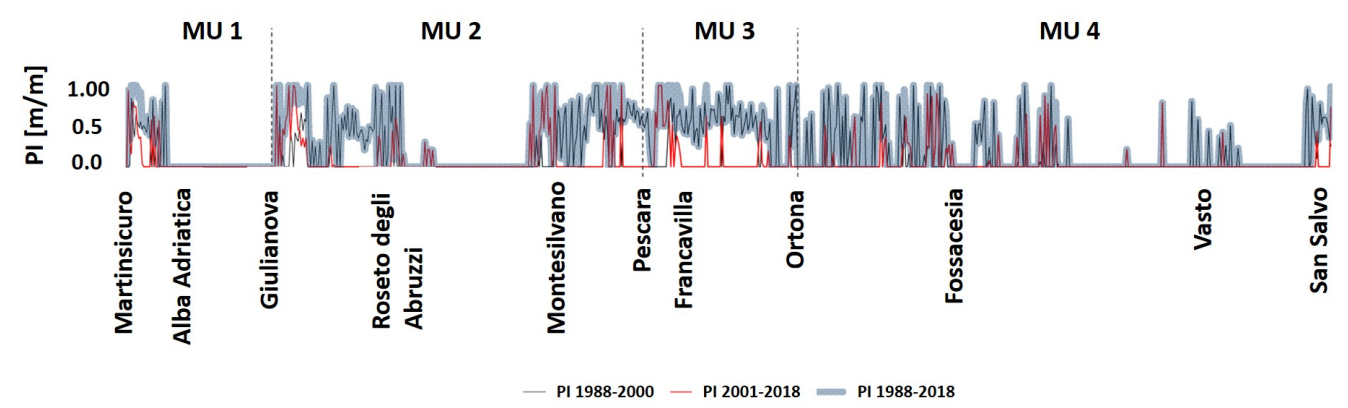

Figure 9. Temporal distribution of the PI for each MU. The black line refers to the structures realized in the period 1988-2000, while the continuous red line refers to those realized in the 2001-2018 period. The grey transparent line indicates the total protection index in the timespan 1988-2018.
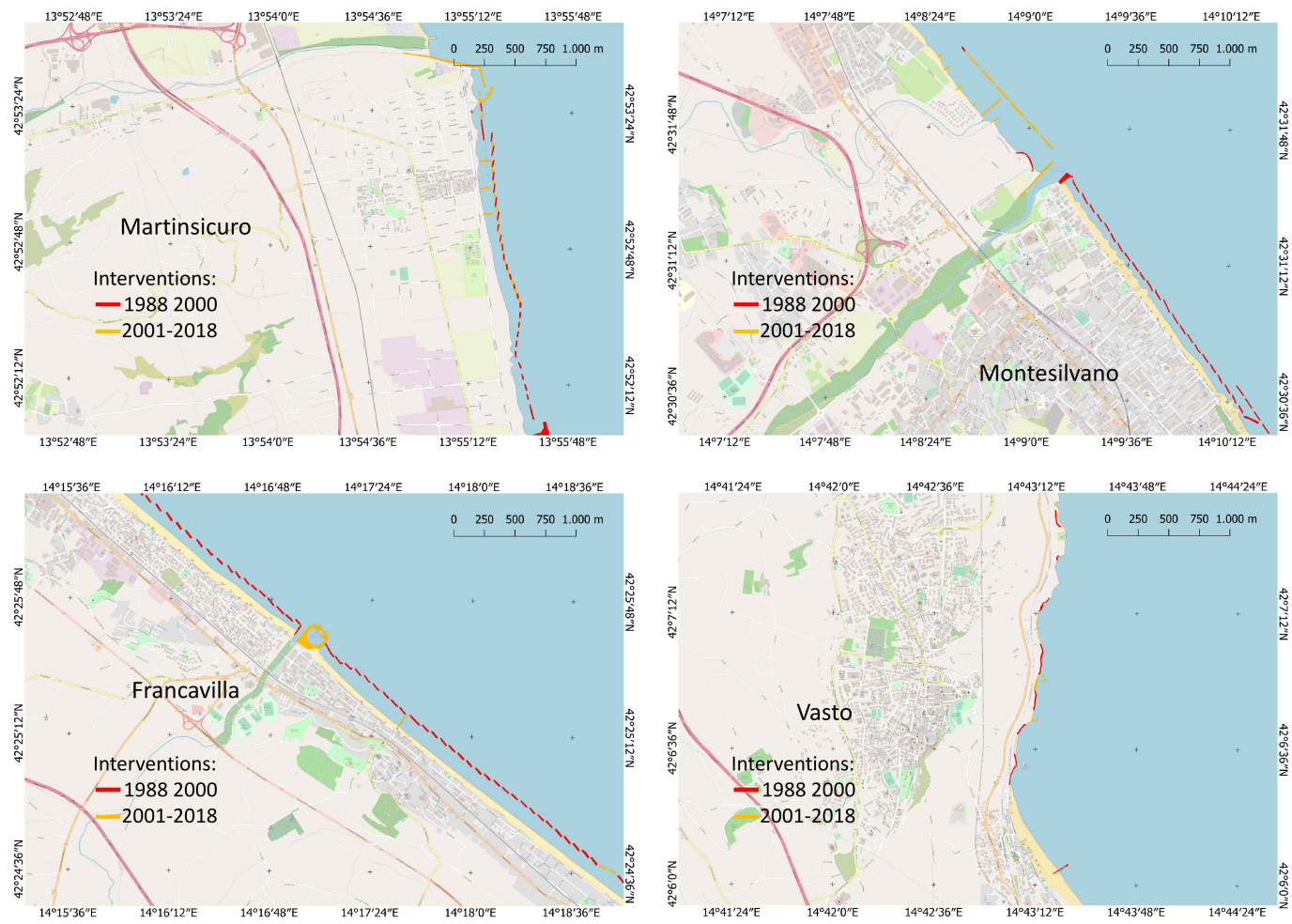

Figure 10. Sketch of the selected areas for each MU that highlights the period in which the structures have been realized.

However, a possible way to quantify the effect of the rigid protection in the study area could be the analysis of the sediment budget (i.e., $\mathrm{m}^{3}$ /year) for each MU. The inspection of the available regional documentation, for the coastal stretch of the Abruzzo Region, the annual value for the closure depth $\left(d_{c}\right)$ is about $6.85 \mathrm{~m}$, while the extension $\left(\Delta_{x}\right)$ of the IA is $500 \mathrm{~m}$. Therefore, the yearly sediment volume can be evaluated as $\Delta Y \times \Delta_{x} \times d_{c}$. Table 2 shows the obtained results.

Table 2. Sediment budget for each MU.

\begin{tabular}{cc}
\hline UF 1 & $10,385.4\left[\mathrm{~m}^{3} /\right.$ year $]$ \\
\hline UF 2 & $22,509.5\left[\mathrm{~m}^{3} /\right.$ year $]$ \\
\hline UF3 & $10,269.1\left[\mathrm{~m}^{3} /\right.$ year $]$ \\
\hline UF4 & $20,284.6\left[\mathrm{~m}^{3} /\right.$ year $]$ \\
\hline
\end{tabular}


As it is possible to see (e.g., Table 2), the general sediment budget is positive for each MU. It has to be stressed that this does not mean the total coastal stretch of each MU is locally advancing, but that the total yearly budget is positive. However, there are areas of negative volume rates compensated by others with higher values, giving final positive results. In the first MU, about $54.5 \%$ of IAs show shoreline retreat, while in the other MUs, the values are about $33.4 \%, 13.5 \%$, and $33.4 \%$ respectively.

The presence of human activities, and the exploitation of coastal areas for economic and touristic purposes, suggested a further investigation on the economy of a coastal area. Considering (as previously underlined) only the activities in the coastal area, there are just more than 16,000 employees (situation at 2017), equivalent to $4.4 \%$ of the total residents of the coastal area.

As it is possible to see from Figure 11, analyzing the ranking of the Abruzzo Region in the national framework, appears that it is in the middle place considering the rank for people working in the selected business sectors.

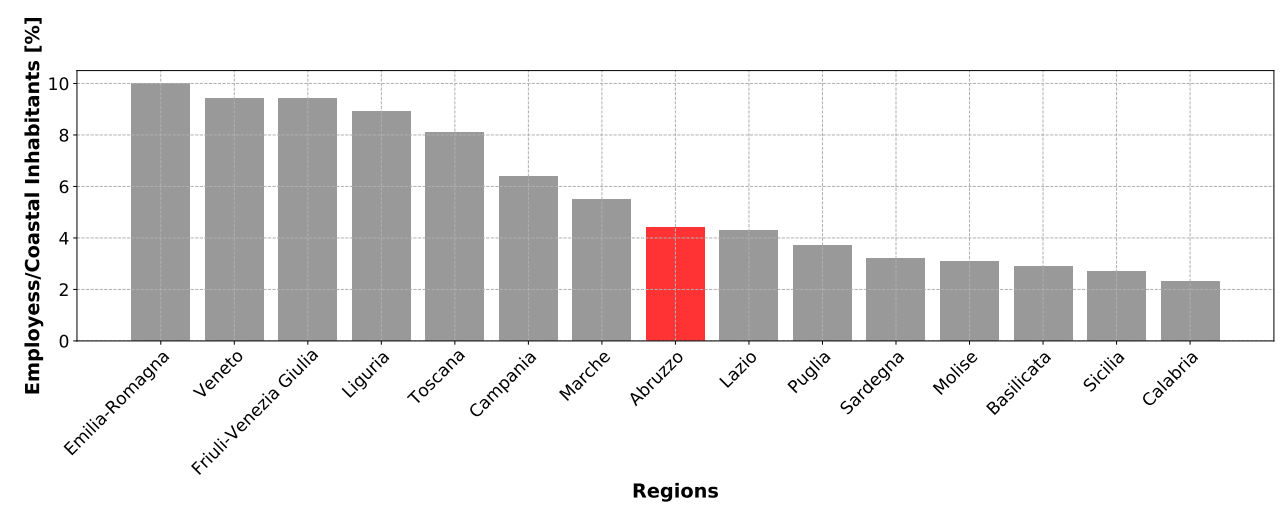

Figure 11. National framework of the people working in the selected ATECO code.

The evaluation of the ILU, reveals a generally positive trend. As shown in Figure 12, the first MU is characterized by a general increase in ILU index, except for the municipality of Tortoreto. It has no rigid structures (i.e., $\mathrm{PI}=0$ ) but it is one of the municipalities with the highest growth of urbanization. In the second MU, there are two municipalities showing negative ILU values, Pineto and Silvi Marina. In this case, the $\Delta Y$ shows an alternation of retreats and advances, with positive values of urbanization growth but, not always evident as for the previous case. The third MU, instead, shows values as low to be considered equal to zero. The southern part (the fourth MU), on the contrary, shows higher values of the considered index indicating a generally positive trend in the growth of the local economy in the coastal area. It has to be stressed that this MU is the only one that shows significant changes in ILU, with (in the case of Fossacesia and San Vito) percentage variation reaching an increase of about $15-20 \%$. Analyzing the local economy, it appears that there is no general trend. However, an increase in urbanization seems to suggest a generalized benefit for local activities. On the other hand, a coastal area prone to shoreline retreat does not always show a decrease in local economy. Furthermore, the attempt to increase the beach width with coastal protection measures does not lead necessarily to an increase in the local economy.

In the Abruzzo Region, the greater performances are linked to the "Costa dei Trabocchi", the most attractive area from a touristic point of view. 

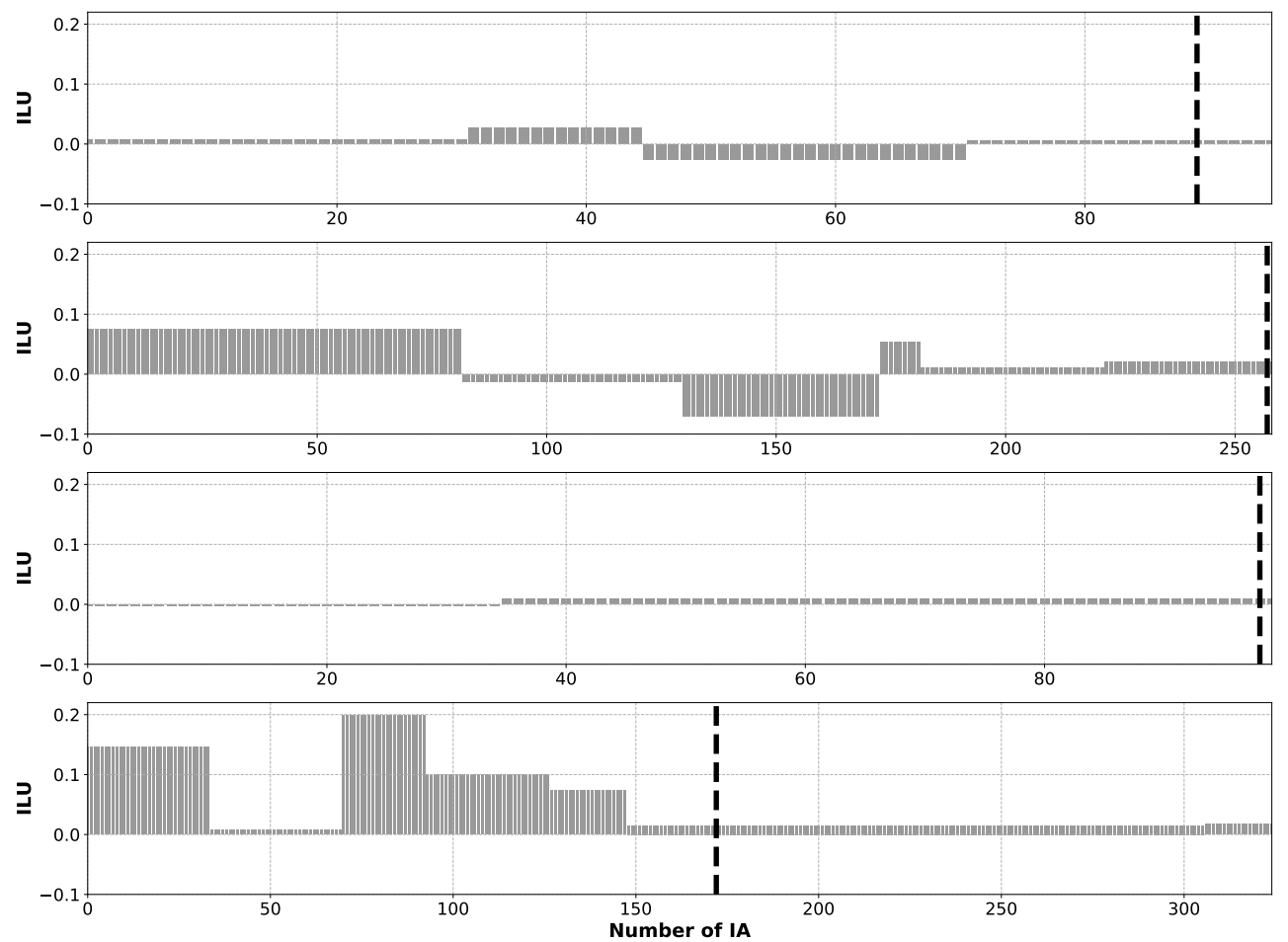

Figure 12. Variarion of the value of the local economic units in the Management Units (see Figure 5). The results are arranged in descending order from north to south from the first management unit (upper panel) to the fourth one (lower panel). The dashed vertical lines indicate the harbor.

\section{Concluding Remarks and Ongoing Research}

This paper aims to analyze and quantify the relationship between urban development, coastal dynamics and the possible effect that the variation of these variables can induce in the local economies. The analysis was performed for the coastal area of the Abruzzo Region (Adriatic Sea, central Italy) by using different types of datasets dividing the coast into four management units considering the harbors of the region as physical boundaries for each unit. At a first glance, results reveal that a direct causal relationship between urban development and erosion phenomena is difficult to find and there is no clear evidence that an increase in urbanization induces a shoreline retreat. This occurrence is due to the fact that, during the years, coastal areas have been protected by using breakwaters and groins in order to fix the local position of the shoreline modifying the hydrodynamics of the area and, therefore, the morphodynamics. Then a protection index, able to weigh the total amount of rigid protection structures against the shoreline length was proposed. Results have shown a general over-protection of the coast using different types of engineering solutions. In order to counteract the progressive increase of beach width demand almost every coastal municipality resorts to hard structures. However, despite this over-protection, the effect on the coastal dynamics and, in particular on the increase of beach width, are less evident than expected.

In general, the majority of the structures induced a localized benefit, not always producing appreciable changes in the shoreline position. Results reveal that the total protection of the MU lead to a general benefit for the beach's width, although generating, in some cases, a series of confined cells (i.e., combining groins and breakwaters) with resulting problems in water quality. However, a clear and generalized conclusion on the real benefit of rigid protection is difficult and it can be assessed only after a comparison with the "do nothing option". Due to the practical difficulties in modeling a "do nothing option" scenario (out of the scope of this paper), the conclusion on the performances of the structure can be only argued. In the case of a predominant wave climate and, therefore a uni-modal direction of sediment transport, groins can induce localized benefit in the updrift area, paying attention to the effect on the downdrift sector. Breakwaters seem to be a good 
attenuation of wave action, useful in particular in the case of protecting beach nourishment avoiding or mitigating the loss of sediments. However, the intensive use of alongshore protection involves benefit, often in the face of sustainable maintenance of natural habitats. Moreover, an analysis of the local economies shows that a generalized protection of the coastal area does not produce a definite benefit to the local economy (i.e., the third MU has high values of PI while ILU can be considered equal to zero). On the contrary, areas with total or partial absence of human presence (i.e., the "Costa dei Trabocchi" area) show significant changes in ILU and, therefore, in the local economies. These results suggest the potential of sustainable tourism in the future development of coastal areas.

The ongoing research is focused on the extension of this work to a national scale in order to have a general picture of the various effect produced by different regional policies in the coastal stretches. The aim will be to understand how different urbanization plans and different engineering solutions act on the coastal system also in view of future climate change scenarios.

Author Contributions: Conceptualization, D.P. and A.M.; methodology, D.P. and A.M.; software, D.P. and A.M.; validation, D.P. and A.M.; formal analysis, D.P. and A.M.; investigation, D.P. and A.M.; resources, D.P. and A.M.; data curation, D.P. and A.M.; writing-original draft preparation, D.P. and A.M.; writing—review and editing, D.P. and A.M.; visualization, D.P. and A.M.; supervision, D.P. and A.M. All authors have read and agreed to the published version of the manuscript.

Funding: This research received no external funding.

Institutional Review Board Statement: Not applicable.

Informed Consent Statement: Not applicable.

Acknowledgments: The authors wish to thank Marcello Di Risio for the fruitful discussions that inspired this work.

Conflicts of Interest: The authors declare no conflict of interest.

\section{References}

1. Curr, R.; Koh, A.; Edwards, E.; Williams, A.; Davies, P. Assessing anthropogenic impact on Mediterranean sand dunes from aerial digital photography. J. Coast. Conserv. 2000, 6, 15-22. [CrossRef]

2. Romano, B.; Zullo, F. The urban transformation of Italy's Adriatic coastal strip: Fifty years of unsustainability. Land Use Policy 2014, 38, 26-36. [CrossRef]

3. Falco, E. Protection of coastal areas in Italy: Where do national landscape and urban planning legislation fail? Land Use Policy 2017, 66, 80-89. [CrossRef]

4. Riitano, N.; Dichicco, P.; De Fioravante, P.; Cavalli, A.; Falanga, V.; Giuliani, C.; Mariani, L.; Strollo, A.; Munafò, M. Land consumption in italian coastal area. Environ. Eng. Manag. J. EEMJ 2020, 19, 1857-1868. [CrossRef]

5. Mentaschi, L.; Vousdoukas, M.I.; Pekel, J.F.; Voukouvalas, E.; Feyen, L. Global long-term observations of coastal erosion and accretion. Sci. Rep. 2018, 8, 12876. [CrossRef]

6. Romano, B.; Zullo, F.; Fiorini, L.; Marucci, A.; Ciabò, S. Land transformation of Italy due to half a century of urbanization. Land Use Policy 2017, 67, 387-400. [CrossRef]

7. Romano, B.; Marucci, A.; Zullo, F.; Ciabò, S.; Fiorini, L.; Giuliani, C.; Olivieri, S. Modelli di pressione insediativa e di retrofit nel governo del territorio nelle aree costiere. RETICULA 2015, 10, 22-27. (In Italian)

8. Romano, B.; Marucci, A.; Zullo, F.; Fiorini, L.; Ciabò, S. Urban pressure and planning management for Italian coastal areas. In Proceedings of the 6th International Symposium Monitoring of Mediterranean Coastal Areas, Problems and Measurement Techniques, Livorno, Italy, 28-29 September 2016.

9. Zullo, F.; Ciabò, S.; Fiorini, L.; Marucci, A.; Olivieri, S.; Perazzitti, S.; Romano, B. Multilevel planning regional management. A GIS Platform Structure. In Heritage and Technology. Mind Knowledge Experience; La Scuola di Pitagora: Naples, Italy, 2015.

10. Salman, A.; Lombardo, S.; Doody, P. Living with Coastal Erosion in Europe: Sediment and Space for Sustainability; Eurosion Project Reports, EUCC; Office for Official Publications of the European Communities: Luxembourg, 2004. Available online: http:/ / resolver.tudelft.nl/uuid:483327a3-dcf7-4bd0-a986-21d9c8ec274e (accessed on 27 May 2021).

11. Pranzini, E.; Wetzel, L.; Williams, A.T. Aspects of coastal erosion and protection in Europe. J. Coast. Conserv. 2015, 19, 445-459. [CrossRef]

12. Syvitski, J.P.; Vörösmarty, C.J.; Kettner, A.J.; Green, P. Impact of humans on the flux of terrestrial sediment to the global coastal ocean. Science 2005, 308, 376-380. [CrossRef] [PubMed]

13. Bird, E.C. Beach Management; John Wiley \& Sons Limited: Hoboken, NJ, USA, 1996; Volume 5. 
14. Gómez-Pina, G.; Muñoz-Pérez, J.J.; Ramírez, J.L.; Ley, C. Sand dune management problems and techniques, Spain. J. Coast. Res. 2002, 325-332. [CrossRef]

15. Williams, A.; Rangel-Buitrago, N.; Pranzini, E.; Anfuso, G. The management of coastal erosion. Ocean Coast. Manag. 2018, 156, 4-20. [CrossRef]

16. Antonioli, F.; Falco, G.D.; Presti, V.L.; Moretti, L.; Scardino, G.; Anzidei, M.; Bonaldo, D.; Carniel, S.; Leoni, G.; Furlani, S.; et al. Relative Sea-Level Rise and Potential Submersion Risk for 2100 on 16 Coastal Plains of the Mediterranean Sea. Water 2020, 12, 2173. [CrossRef]

17. Scardino, G.; Sabatier, F.; Scicchitano, G.; Piscitelli, A.; Milella, M.; Vecchio, A.; Anzidei, M.; Mastronuzzi, G. Sea-Level Rise and Shoreline Changes Along an Open Sandy Coast: Case Study of Gulf of Taranto, Italy. Water 2020, 12, 1414. [CrossRef]

18. Dias, A.; Curr, J.; Davies, R.; Pereira, P.; Williams, A. Dune vulnerability and management: Portugal and North-West Europe. In Littoral 94 Proceedings; Eurocoast-Portugal Association: Porto, Portugal, 1994; pp. 837-848.

19. De Luca, E.; Novelli, C.; Barbato, F.; Menegoni, P.; Iannetta, M.; Nascetti, G. Coastal dune systems and disturbance factors: Monitoring and analysis in central Italy. Environ. Monit. Assess. 2011, 183, 437-450. [CrossRef]

20. Young, I.R.; Ribal, A. Multiplatform evaluation of global trends in wind speed and wave height. Science 2019, 364, 548-552. [CrossRef]

21. Oppenheimer, M.; Glavovic, B.; Hinkel, J.; van de Wal, R.; Magnan, A.K.; Abd-Elgawad, A.; Cai, R.; Cifuentes-Jara, M.; Deconto, R.M.; Ghosh, T.; et al. Sea Level Rise and Implications for Low Lying Islands, Coasts and Communities. 2019. Available online: https://www.ipcc.ch/srocc/chapter/chapter-4-sea-level-rise-and-implications-for-low-lying-islands-coastsand-communities / (accessed on 15 December 2020).

22. Pasquali, D.; Di Risio, M.; De Girolamo, P. A simplified real time method to forecast semi-enclosed basins storm surge. Estuar. Coast. Shelf Sci. 2015, 165, 61-69. [CrossRef]

23. Bakkensen, L.A. Mediterranean hurricanes and associated damage estimates. J. Extrem. Events 2017, 4, 1750008. [CrossRef]

24. Pasquali, D.; Bruno, M.; Celli, D.; Damiani, L.; Di Risio, M. A simplified hindcast method for the estimation of extreme storm surge events in semi-enclosed basins. Appl. Ocean Res. 2019, 85, 45-52. [CrossRef]

25. Scicchitano, G.; Scardino, G.; Tarascio, S.; Monaco, C.; Barracane, G.; Locuratolo, G.; Milella, M.; Piscitelli, A.; Mazza, G.; Mastronuzzi, G. The First Video Witness of Coastal Boulder Displacements Recorded during the Impact of Medicane "Zorbas" on Southeastern Sicily. Water 2020, 12, 1497. [CrossRef]

26. Hadley, D. Land use and the coastal zone. Land Use Policy 2009, 26, S198-S203. [CrossRef]

27. Di Risio, M.; Bruschi, A.; Lisi, I.; Pesarino, V.; Pasquali, D. Comparative analysis of coastal flooding vulnerability and hazard assessment at national scale. J. Mar. Sci. Eng. 2017, 5, 51. [CrossRef]

28. Richards, D.R.; Friess, D.A. Characterizing coastal ecosystem service trade-offs with future urban development in a tropical city. Environ. Manag. 2017, 60, 961-973. [CrossRef]

29. Wasson, K.; Woolfolk, A.; Fresquez, C. Ecotones as indicators of changing environmental conditions: Rapid migration of salt marsh-upland boundaries. Estuaries Coasts 2013, 36, 654-664. [CrossRef]

30. Van Rijn, L. Coastal erosion and control. Ocean Coast. Manag. 2011, 54, 867-887. [CrossRef]

31. Pranzini, E. Shore protection in Italy: From hard to soft engineering. .. and back. Ocean Coast. Manag. 2018, 156, 43-57. [CrossRef]

32. Di Risio, M.; Lisi, I.; Beltrami, G.; De Girolamo, P. Physical modeling of the cross-shore short-term evolution of protected and unprotected beach nourishments. Ocean Eng. 2010, 37, 777-789. [CrossRef]

33. Di Risio, M.; Pasquali, D.; Lisi, I.; Romano, A.; Gabellini, M.; De Girolamo, P. An analytical model for preliminary assessment of dredging-induced sediment plume of far-field evolution for spatial non homogeneous and time varying resuspension sources. Coast. Eng. 2017, 127, 106-118. [CrossRef]

34. Saponieri, A.; Di Risio, M.; Pasquali, D.; Valentini, N.; Aristodemo, F.; Tripepi, G.; Celli, D.; Streicher, M.; Damiani, L. Beach profile evolution in front of storm seawalls: A physical and numerical study. Coast. Eng. Proc. 2018, 70. [CrossRef]

35. Fischione, P.; Celli, D.; Pasquali, D.; Di Risio, M. Drains Inlfuence on the beach groundwater Hydrodynamics. Ital. J. Eng. Geol. Environ. 2020, 2020, 41-47.

36. Paganelli, D.; Nonnis, O.; Finoia, M.G.; Gabellini, M. The role of sediment characterization in environmental studies to assess the effect of relict sand dredging for beach nourishment: The example of offshore sand deposits in Lazio (Tyrrhenian Sea). J. Coast. Res. 2013, 1015-1020. [CrossRef]

37. Pranzini, E.; Anfuso, G.; Muñoz-Perez, J.J. A probabilistic approach to borrow sediment selection in beach nourishment projects. Coast. Eng. 2018, 139, 32-35. [CrossRef]

38. De Vincenzo, A.; Covelli, C.; Molino, A.J.; Pannone, M.; Ciccaglione, M.; Molino, B. Long-term management policies of reservoirs: Possible re-use of dredged sediments for coastal nourishment. Water 2019, 11, 15. [CrossRef]

39. Celli, D.; Pasquali, D.; De Girolamo, P.; Di Risio, M. Effects of submerged berms on the stability of conventional rubble mound breakwaters. Coast. Eng. 2018, 136, 16-25. [CrossRef]

40. Celli, D.; Li, Y.; Ong, M.C.; Di Risio, M. The role of submerged berms on the momentary liquefaction around conventional rubble mound breakwaters. Appl. Ocean Res. 2019, 85, 1-11. [CrossRef]

41. Celli, D.; Li, Y.; Ong, M.C.; Di Risio, M. Random Wave-Induced Momentary Liquefaction around Rubble Mound Breakwaters with Submerged Berms. J. Mar. Sci. Eng. 2020, 8, 338. [CrossRef] 
42. Scipione, F.; Di Risio, M.; Castellino, M.; Pasquali, D.; De Girolamo, P. Wave induced hydrodynamics field around the long submerged groin of the latina (Italy) nuclear power plant cooling system intake. In Proceedings of the 9th Short Course/Conference on Applied Coastal Research, Bari, Italy, 9-11 September 2019; pp. 98-103.

43. Longuet-Higgins, M.S. Longshore currents generated by obliquely incident sea waves: 1. J. Geophys. Res. 1970, 75, 6778-6789. [CrossRef]

44. Pranzini, E.; Anfuso, G.; Cinelli, I.; Piccardi, M.; Vitale, G. Shore protection structures increase and evolution on the Northern Tuscany Coast (Italy): Influence of tourism industry. Water 2018, 10, 1647. [CrossRef]

45. Dean, R.G.; Dalrymple, R.A. Water Wave Mechanics for Engineers and Scientists; World Scientific Publishing Company: Singapore, 1991; Volume 2.

46. Dean, R.G.; Dalrymple, R.A. Coastal Processes with Engineering Applications; Cambridge University Press: Cambridge, UK, 2004.

47. Niesing, H. EUROSION: Coastal erosion measures, knowledge and results acquired through 60 studies. In Proceedings of Dunes Estuaries-International Conference on Nature Restoration Practices in European Coastal Habitats, Koksijde, Belgium, 19-23 September 2005; pp. 421-431.

48. Munafò, M.C.D. Consumo di Suolo, Dinamiche Territorialie Servizi Ecosistemici; Technical Report 288/2018; Italian National Institute for Environmental Protection and Research (ISPRA): Rome, Italy, 2018. (In Italian)

49. Hallermeier, R.J. A profile zonation for seasonal sand beaches from wave climate. Coast. Eng. 1980, 4, 253-277. [CrossRef]

50. Hallermeier, R.J. Sand transport limits in coastal structure designs. In Coastal Structures' 83; ASCE: Arlington, VA, USA, 1983; pp. 703-716.

51. Larson, M.; Hanson, H.; Kraus, N.C. Analytical solutions of one-line model for shoreline change near coastal structures. J. Waterw. Port Coast. Ocean Eng. 1997, 123, 180-191. [CrossRef]

52. Vitousek, S.; Barnard, P.L.; Limber, P.; Erikson, L.; Cole, B. A model integrating longshore and cross-shore processes for predicting long-term shoreline response to climate change. J. Geophys. Res. Earth Surf. 2017, 122, 782-806. [CrossRef]

53. Robinet, A.; Idier, D.; Castelle, B.; Marieu, V. A reduced-complexity shoreline change model combining longshore and cross-shore processes: The LX-Shore model. Environ. Model. Softw. 2018, 109, 1-16. [CrossRef]

54. Council Regulation (EEC) No 696/93 of 15 March 1993 on the statistical units for the observation and analysis of the production system in the Community. Off. J. L 076 30/03/1993 P. 0001-0011 1993, 24. Available online: https: / / eur-lex.europa.eu/LexUriServ/ LexUriServ.do?uri=CELEX:31993R0696:EN:HTML (accessed on 15 December 2020).

55. Romano, B.; Zullo, F.; Ciabò, S.; Fiorini, L.; Marucci, A.I.I. Geografie e modelli di 50 anni di consumo di suolo in Italia. Sci. E Ric. 2015, 6, 17-28.

56. The European Commission. Commission Implementing Decision (EU) 2020/96 of 28 November 2019 Adopting the Thirteenth Update of the List of Sites of Community Importance for the Mediterranean Biogeographical Region (Notified under Document C(2019) 8583); The European Commission, Directorate-General for Environmen: Brussels, Belgium, 2020.

57. The European Commission. Commission Implementing Decision (EU) 2020/97 of 28 November 2019 Adopting the Thirteenth Update of the List of Sites of Community Importance for the Continental Biogeographical Region (Notified under Document C(2019) 8586); The European Commission, Directorate-General for Environment: Brussels, Belgium, 2020.

58. The European Commission. Commission Implementing Decision (EU) 2020/100 of 28 November 2019 Adopting the Thirteenth Update of the List of Sites of Community Importance for the Alpine Biogeographical Region (Notified under Document C(2019) 8589); The European Commission, Directorate-General for Environment: Brussels, Belgium, 2020.

59. Valentini, N.; Saponieri, A.; Molfetta, M.G.; Damiani, L. New algorithms for shoreline monitoring from coastal video systems. Earth Sci. Inform. 2017, 10, 495-506. [CrossRef]

60. Romano, B.; Fiorini, L.; Marucci, A.; Zullo, F. The urbanization run-up in Italy: From a qualitative goal in the boom decades to the present and future unsustainability. Land 2020, 9, 301. [CrossRef] 